\title{
Auditing of Subsequent Events: A Survey of Auditors in the City of Istanbul in Turkey
}

\author{
Zehra Ozdemir ${ }^{1}$ \& Basak Ataman Gokcen ${ }^{2}$ \\ ${ }^{1}$ The Institute of Social Sciences in Accounting and Finance, Marmara University, Turkey \\ ${ }^{2}$ Faculty of Business Administration, Marmara Universitesi, Istanbul, Turkey \\ Correspondence: Zehra Ozdemir, The Institute of Social Sciences in Accounting and Finance, Marmara University, \\ Turkey. Tel: 1-669-226-9253
}

Received: January 25, 2016

Accepted: April 5, 2016

Online Published: April 8, 2016

doi:10.5430/afr.v5n2p42

URL: http://dx.doi.org/10.5430/afr.v5n2p42

\begin{abstract}
Unlimited numbers of events which can occur after the reporting period, but before board approval of financial statements (subsequent events), can have important effects on financial statements, independent audit opinion, investors and other related parties with the financial reporting system. The Capital Market Boards have shortened the time between the balance sheet date and report release date, thus potential subsequent events may affect the entire audit process. This reduction narrowed the legally allowed period of the preparation of financial statements. Moreover, the reduction limited the processes of obtaining, searching and evaluating evidence of subsequent events, since the majority of the audit work will be performed after the balance sheet date. The aim of this paper is to examine subsequent event audit experiences and the process of searching for evidence, and to measure the importance level of disclosures, perception level and use of Turkish Independent Auditing Standard 560.
\end{abstract}

Keywords: Subsequent Events, International Auditing Standards, Financial Statement Audit

JEL Classifications: C83, M42, M48.

\section{Introduction}

Financial statement audit is a systematic process in which objective forms of evidence between the claims on economic events and predetermined criteria (Gramling, Johnstone \& Littenberg, 2012) are obtained, assessed and reported to related parties. The auditor tests the accuracy of the information alleged by the management in the financial statements. The auditor can start the substantive testing after preparation and presentation of required data, information and statements to the auditor. Completing audit tests and preparing audit reports requires a certain amount of time, often taking up to three months of the following year. In this case, the auditor is responsible for events which have occurred between the dates of the balance sheet and audit report (Uyar, 2014). If there is no specific accounting period indicated, the balance sheet date is usually considered 12. 31. XX. In other words, the audit is a sustained concept, examining and assessing the important events between the balance sheet date and audit report date (Bozkurt, 2009). The events should be assessed by the auditor after the audit period according to International Accounting Standards 10 - Events after the Reporting Period (IAS 10) and split into two types, as specified in the standard. These two types are adjusting events and non-adjusting events. Adjusting events arise from the events and conditions actualized within the reported financial period, which means these events already existed and were actualized before the balance sheet date, but for some reason the impact was not certain or had not yet resulted up to the balance sheet date. Financial statements should be adjusted to reflect adjusting events after the balance sheet date. Non-adjusting events are the events actualized after the balance sheet date. Non-adjusting events arise from the events and conditions actualized after the balance sheet date and have no impact on the reported financial period. (Puttick \& Esch, 2007; Mirza, Holt \& Orrell, 2006).

The unlimited number of possible events arising after the balance sheet date but before the audit report approval date can have important effects on financial statements, audit opinions, investigation decisions and other financial reporting system related parties. These effects are audited in Turkey within the scope of 6102 Numbered Turkish Commercial Law of International Auditing Standards. Turkey is one of the most important emerging countries with a rapidly developing and growing economy. Further, Turkey follows new developments in the financial reporting area and has become one of the earliest adopters of the International Accounting Standards / International Financial Reporting Standards and International Auditing Standards in the world (Kılıç, Uyar \& Ataman, 2014). As a result of 
these developments, companies which are not publicly traded, but subject to the criteria determined by the Council of Ministers are required to get an independent audit (Gücenme, Arsoy, Ertan \& Bora, 2014).

The issue date of the financial statements is critical for the audit of subsequent events. The Capital Market Boards of Turkey moved up the financial statement release date from 98 days and 70 days after the balance sheet date to 70 days and 60 days respectively for annual consolidated and individual financial statements (2013). This change in the deadline of financial statement announcements and issuing directly affected the time period of financial statement preparation and reporting. Accordingly, the shrinkage in the window of time between the balance sheet date and reporting date also directly affected the time frame of the obtaining, searching and reporting processes for subsequent event evidence (Janvrin \& Jeffrey, 2007). Subsequent events which are critical for the audit process are also examined by the regulators. Auditing of subsequent events are examined and indicated in the International Standard of Auditing 560 (ISA 560) and statements of Auditing Standards Section 560. The Turkish Independent Auditing Standard 560 (BDS 560) which is used in the audit of subsequent events in Turkey is literally the translation and conversion of ISA 560. Auditors are one of the most important actors in the adoption process of international standards in Turkey. Their support is needed for an effective adoption (Kılıç et al. 2014). This research has been conducted and prepared in light of following three goals: The first goal was to realize the evidence-obtaining process by examining the audit experience of auditors regarding subsequent events. The second was to determine the utilization level of Turkish Independence Auditing Standards in subsequent events auditing. The last was to detect the perception level of significance regarding subsequent events.

This study will significantly contribute to the existing literature in various ways. Firstly, it has been observed that scientific studies regarding the subsequent events in the scope of International Accounting Standard 10 mostly focus on definitions, recognition and disclosures (Muthupandian, 2008; Fitzsimons, Pappas \& Ramanujam, 2009; Pamukçu \& Pamukçu, 2009; Sümer \& Erer, 2009; Rossi III, 2011; Turel, 2012; Yükçü \& Yaşar, 2013; Şen, 2015). There are only a few studies which have examined subsequent events within the scope of auditing standards (Janvrin \& Jeffrey, 2007; Chung et al., 2013; Herda \& Lavelle 2014). This study has been prepared to fill this gap by examining subsequent events within the scope of International Auditing Standards. Secondly, in this study, the subsequent events which have occurred between the years 2009 and 2013 in public companies quoted to the Turkey Capital Market Boards have been examined. Although one recent study determined the subsequent events for a one-year financial period (Y1lmaz \& Sar1, 2013), in this study we examined five years' data. Thirdly, subsequent events based on the international standards in this study were presented to the auditors. Therefore, this study produced a level of compliance with international standards in Turkey. This study might be interesting for regulators who must determine appropriate enforcement actions in similar emerging countries.

The next section reviews the literature. Then, methodology and data are presented. In the fourth part, the results of the research are discussed. Finally, the last section concludes the paper.

\section{Literature Review}

Scientific studies related to subsequent events in Turkey seem to focus on the recognition and description within IAS 10. When we examined the foreign literature, there was little academic research on the subject, and the studies that existed mentioned the lack of concern about subsequent event studies. The following review primarily concentrates on studies concerning IAS 10, then briefly discusses studies of the auditing area.

Yilmaz and Sarı (2013) examined subsequent events disclosures of entities in Borsa, Istanbul 100 (BIST 100) during the period of 2011 by evaluating the scope of IAS 10 . The authors reported that $63 \%$ of entities had subsequent event disclosure, but $37 \%$ of entities had no subsequent event disclosure. There was determined to be a 2.7 disclosure type per entity. The top subsequent events category is subsidiaries or affiliates disclosures, with a rate of $21 \%$, then securities (7\%), tangible assets (7\%), capital (6\%), and investment allowance (5\%) were the explanation issues.

Giacosa (2012) examined 45 enterprises in the Italy Stock Exchange FTSE index that operated in the consumer goods industry in 2010. In particular, the author gathered information about the disclosure level and structure required by the IAS 10 financial statements. The author classified the disclosures required by the IAS 10 and found that, whereas all the entities announced the financial statements, approval date and the board or persons approving the financial statements, only $75 \%$ described the effects of subsequent events on financial statements.

Ozdemir and Ataman Gokcen (2015) determined the situation of subsequent event disclosures between years 2009 and 2013 for public real sector companies which operate in Turkey. Within this context, sets of financial statements and disclosures of public real sector companies were examined utilizing the content analysis method. In this study, it was observed that the majority of the subsequent events disclosed by companies throughout the 5-year period consisted of subsidiaries, affiliates and other related-party explanations by the companies. According to this study, 
the average publication periods for the consolidated financial statement and the individual financial statements were determined respectively to be 77 days and 66 days after the financial statement date.

Janvrin and Jeffrey (2007) indicated the reason for their study is that SEC reporting requirements reduced the time between the balance sheet and report dates, limiting the availability of subsequent event evidence. This study's goals were to verify that auditors perceive subsequent event evidence to be important, understand the process auditors employ to search for subsequent event evidence and examine factors influencing this process. For this purpose, they used an experiential questionnaire and provided responses from the auditors who were employees in Big 4 firms and one national firm. Results indicated that auditors perceive subsequent event evidence to be important to the audit process. Approximately $75 \%$ of respondents typically perform the majority of fieldwork after the balance sheet date. Auditors generally follow procedures recommended by audit standards to search for subsequent event evidence. Auditors are more likely to search for and find subsequent event evidence when minimal historical evidence exists and their balance sheet date judgments do not meet prior expectations. Auditors are more likely to search for evidence when evaluating non-routine account balances that potentially impact the financial statements as a whole rather than one account, and when they have ample time to search. Auditors are more likely to find subsequent event evidence that is consistent, rather than inconsistent, with their balance sheet date judgment and when the search period is longer. Finally, time pressure does not impact whether auditors perceive that they find significant subsequent event evidence.

Chang et al.'s paper (2012) integrated the psychological and behavioral accounting literatures to develop a model of the factors that influence the effectiveness of subsequent event audit procedures. They analyzed Securities and Exchange Commission (SEC) enforcement releases and Public Company Accounting Oversight Board (PCAOB) inspection reports related to subsequent events and determined that properly identifying, evaluating, and resolving subsequent events can be problematic, both for management and auditors. Approximately one-third of the PCAOB's inspection reports and several SEC enforcement releases identify deficiencies in the audit of subsequent events. This model provides a theoretical basis for future research into the causes of these deficiencies and suggests potential mitigating strategies that auditors can employ to improve the effectiveness of the audit of subsequent events. They also identify key research opportunities and propose a series of research questions arising from the model. In conclusion, this paper addresses the importance of auditing subsequent events adequately, an inherently complex process requiring the careful application of professional judgment.

Herda and Lavelle (2014) add to the subsequent audit literature by analyzing auditors' open-ended responses to questions on factors that may influence subsequent events searches, evaluation, negotiation and resolution, sources of subsequent audit difficulties and ways to improve the auditing of subsequent events. In this paper, they address several of Chung et al.'s (2012) questions by surveying 76 practicing auditors in the United States. As a conclusion of this research the authors suggest some practical implications. Auditors should consider subsequent event implications throughout the substantive testing phase of the audit and may also wish to question client personnel outside of financial management as part of their normal subsequent event audit procedure. Audit firm management should work to ensure that all audit team members have an appropriate level of client and industry knowledge, as this may impact their ability to identify and evaluate subsequent events.

Nawaiseh and Javer (2015) developed a questionnaire to identify to what extent auditors in Jordan comply with the requirements of the ISA 560. The authors tested their hypotheses using a randomly-selected sample of 62 auditors working in auditing offices. The study showed that the auditors in the Jordanian auditing firms were familiar with the requirements of the ISA 560 regarding auditing of subsequent events in the period between the balance sheet date and the audit report date. The study shows also that the personal characteristics of the auditors (experience, CPA exams, education) did not have statistically significant effects on their awareness of the importance of compliance with the requirements of this standard.

\section{Data and Method}

The population of the study was made up of independent auditors who have Public Oversight Accounting and Auditing Standards Authority's Independent Auditor Official Registry and work in Istanbul. The sample of the study consisted of 108 independent auditors. A questionnaire was used as a data collection instrument. Questionnaires were administered by e-mail. We addressed several of these questions arising from Janvrin and Jeffrey (2007) and Chung et al.'s surveys (2012) and investigated_the subsequent events in the traded companies in Turkey. Before sending out the questionnaire, we contacted 91 independent auditing firms via telephone, as authorized by the Turkish Public Oversight Accounting and Auditing Standards Authority. We then sent e-mails according to the responses from the firms. Questionnaires were collected during the months of June, July, and August of 2014.

The responses were measured on a five-point Likert scale. The questionnaire included seven sections. Two of the 
sections collected demographic information on the auditors, one relating to personal information and the other to information about the firm. The third section was comprised of the questions related to audit experiences on subsequent events. Questions aimed at obtaining subsequent events evidence were posed in fourth section of questionnaire. The importance of the subsequent events disclosures to the auditors was assessed through the items in the fifth section. Questions in the sixth section of the questionnaire were related to the perceptions of independent auditors regarding subsequent events. The statements in the last section were aimed at determining the application level of audit procedures of BDS 560.

Descriptive statistics of the respondents are given in Table 1. According to the findings, $65 \%$ of participants worked in the international audit firms, and $70 \%$ of participants audited for non-listed companies. More than half the participants $(52 \%)$ worked in firms with at least 21 auditors, considered medium- and large-sized firms in Turkey. Most of the participants $(70.37 \%$ ) had a bachelor's degree. A total of $70.37 \%$ of the audit professionals had the title "auditor" or higher. Most rated their knowledge level of the international accounting and auditing standards as good. Other details regarding the survey respondents are presented in Table 1.

Table 1. Descriptive Analysis

\begin{tabular}{|c|c|c|c|c|}
\hline & & Number & Percent & Mean \\
\hline \multirow[t]{2}{*}{ Type of firm } & Regional & 38 & $35.19 \%$ & \multirow{2}{*}{1.6481} \\
\hline & International & 70 & $64.81 \%$ & \\
\hline \multirow[t]{2}{*}{ Type of client } & Listed companies & 33 & $30.56 \%$ & \multirow{2}{*}{1.6944} \\
\hline & Non-listed companies & 75 & $69.44 \%$ & \\
\hline \multirow[t]{5}{*}{ Number of auditors in office } & 1 & 7 & $6.48 \%$ & \multirow{5}{*}{3.9630} \\
\hline & $2-5$ & 13 & $12.04 \%$ & \\
\hline & $6-10$ & 14 & $12.96 \%$ & \\
\hline & $11-20$ & 17 & $15.74 \%$ & \\
\hline & $21+$ & 57 & $52.78 \%$ & \\
\hline \multirow[t]{3}{*}{ Education level } & Bachelor degree & 76 & $70.37 \%$ & \multirow{3}{*}{1.3704} \\
\hline & Master degree & 24 & $22.22 \%$ & \\
\hline & PHD & 8 & $7.41 \%$ & \\
\hline \multirow[t]{6}{*}{ Age category } & $20-25$ & 21 & $19.44 \%$ & \multirow{6}{*}{2.5278} \\
\hline & $26-30$ & 35 & $32.41 \%$ & \\
\hline & $31-40$ & 33 & $30.56 \%$ & \\
\hline & $41-50$ & 12 & $11.11 \%$ & \\
\hline & $51-60$ & 7 & $6.48 \%$ & \\
\hline & $60+$ & 0 & $0.00 \%$ & \\
\hline \multirow[t]{5}{*}{ Title of job } & Responsible head partner & 11 & $10.19 \%$ & \multirow{5}{*}{3.7037} \\
\hline & Head partner & 7 & $6.48 \%$ & \\
\hline & Senior associate & 17 & $15.74 \%$ & \\
\hline & Auditor & 41 & $37.96 \%$ & \\
\hline & Assistant auditor & 32 & $29.63 \%$ & \\
\hline \multirow[t]{4}{*}{ Number of auditors supervised } & $0-1$ & 44 & $40.74 \%$ & \multirow{4}{*}{2.2222} \\
\hline & $2-4$ & 31 & $28.70 \%$ & \\
\hline & $4-8$ & 13 & $12.04 \%$ & \\
\hline & $9-15$ & 5 & $4.63 \%$ & \\
\hline \multirow[t]{4}{*}{ International accounting standards knowledge level } & Few & 8 & $7.41 \%$ & \multirow{4}{*}{2.7685} \\
\hline & Medium & 35 & $32.41 \%$ & \\
\hline & Good & 39 & $36.11 \%$ & \\
\hline & Very good & 26 & $24.07 \%$ & \\
\hline \multirow[t]{4}{*}{ International auditing standards knowledge level } & Few & 6 & $5.56 \%$ & \multirow{4}{*}{2.8333} \\
\hline & Medium & 33 & $30.56 \%$ & \\
\hline & Good & 42 & $38.89 \%$ & \\
\hline & Very good & 27 & $25.00 \%$ & \\
\hline
\end{tabular}




\section{Results and Discussion}

\subsection{Audit Experiences on Subsequent Events}

In this section the findings of audit experiences on subsequent events will be evaluated. When we asked participants when they perform the majority of the fieldwork in a typical audit, $44.4 \%$ stated that it is performed on and after the balance sheet date, $25.93 \%$ during the interim, $21.3 \%$ on the balance sheet date and $8.33 \%$ of participants on immediately before the balance sheet date. In this case most of the participants $(65.7 \%)$ performed the majority of fieldwork on and after the balance sheet date. Subsequent events occurred during the period between the financial statement date and approval date. For this reason, the processes are fitted that the auditors' majority of fieldwork and searched subsequent events evidence. However, the Capital Market Boards' 2013 reduction of the time allowed between the balance sheet and report date has directly narrowed the window of the searching period for subsequent events evidence and a large part of fieldwork.

According to the responses, most of the auditors $(84.26 \%$, mean $=2.8)$ obtained subsequent event evidence related to the previous financial year at least once. In regard to the statutory deadlines of the Capital Market Boards (for consolidated financial statements $=70$ days, for individual financial statements $=60$ days), the results of the survey showed that participants have sufficient time to search for subsequent events evidence, as only $11.11 \%$ of participants stated that they had obtained subsequent events evidence 90 days or more after the balance sheet date.

The experiences of the auditors about the amount of time spent performing the searching subsequent event evidence were ascertained. $57.41 \%$ of the respondents work on subsequent events evidence a maximum of 4 hours, whereas $4.63 \%$ work more than 20 hours. Hence, the risk of missed evidence is increased if we considered the performance time for searching evidence.

The participants were asked whether the subsequent event evidence was in the category of adjusting events, non-adjusting events or both. Most of the participants (45.37\%) had subsequent event evidence in the category of non-adjusting events, whereas $16.67 \%$ stated that the evidence required adjustments in financial statements. Almost all of the participants $(86.11 \%)$ used specific procedures for subsequent events audit. Details of the findings regarding audit experiences are presented in Table 2.

Table 2. The Frequency of Audit Experiences on Subsequent Events

\begin{tabular}{|c|c|c|c|c|}
\hline & & Number & Percent & Mean \\
\hline \multirow{4}{*}{$\begin{array}{l}\text { Time when auditor performs } \\
\text { majority of fieldwork in typical } \\
\text { audit }\end{array}$} & $\begin{array}{l}\text { During interim (i.e. } 5 \text { weeks } \\
\text { longer before balance sheet date) }\end{array}$ & or 28 & $25.93 \%$ & \multirow{4}{*}{2.8426} \\
\hline & $\begin{array}{l}\text { Immediately before balance sheet } \\
\text { date }\end{array}$ & t 9 & $8.33 \%$ & \\
\hline & On balance sheet date & 23 & $21.30 \%$ & \\
\hline & After balance sheet date & 48 & $44.44 \%$ & \\
\hline \multirow{4}{*}{$\begin{array}{l}\text { Number of times participant } \\
\text { discovered subsequent event } \\
\text { evidence in past year }\end{array}$} & Never & 17 & $15.74 \%$ & \multirow{4}{*}{2.8056} \\
\hline & Once & 32 & $29.63 \%$ & \\
\hline & Twice & 14 & $12.96 \%$ & \\
\hline & More than twice & 45 & $41.67 \%$ & \\
\hline \multirow{4}{*}{$\begin{array}{l}\text { Number of days following } \\
\text { balance sheet date subsequent } \\
\text { event evidence was discovered }\end{array}$} & 5 days & 24 & $22.22 \%$ & \multirow{4}{*}{2.2129} \\
\hline & 30 days & 49 & $45.37 \%$ & \\
\hline & 60 days & 23 & $21.30 \%$ & \\
\hline & 90 days & 12 & $11.11 \%$ & \\
\hline \multirow{5}{*}{$\begin{array}{l}\text { Subsequent event evidence effort } \\
\text { level }\end{array}$} & $<2$ hours & 33 & $30,56 \%$ & \multirow{5}{*}{2,3425} \\
\hline & Between 2 and 4 hours & 29 & $26.85 \%$ & \\
\hline & Between 5 and 10 hours & 27 & $25.00 \%$ & \\
\hline & Between 10 and 20 hours & 14 & $12.96 \%$ & \\
\hline & $>20$ hours & 5 & $4.63 \%$ & \\
\hline
\end{tabular}




\begin{tabular}{|c|c|c|c|c|}
\hline \multirow[t]{3}{*}{$\begin{array}{l}\text { Type of subsequent events audit } \\
\text { evidence }\end{array}$} & $\begin{array}{l}\text { The conditions were on financial } \\
\text { statement date in related to event } \\
\text { existed. }\end{array}$ & 18 & $16.67 \%$ & \multirow{3}{*}{2.2130} \\
\hline & $\begin{array}{l}\text { The event actualized after } \\
\text { financial statement date. }\end{array}$ & 49 & $45.37 \%$ & \\
\hline & Both of them & 41 & $37.96 \%$ & \\
\hline \multirow{2}{*}{$\begin{array}{lcr}\begin{array}{l}\text { Whether } \\
\text { subsequent }\end{array} & \text { auditors } & \text { have } \\
\text { procedures } & & \text { search }\end{array}$} & Yes & 93 & $86.11 \%$ & \multirow[b]{2}{*}{1.1389} \\
\hline & No & 15 & $13.89 \%$ & \\
\hline
\end{tabular}

4.2 Obtaining Subsequent Events Evidence

Questions aimed at obtaining subsequent events evidence will be considered in this section. It is observed that 56.48\% of the participants thought that subsequent event evidence is not found by random accident. The majority of the respondents (mean $=2.49)$ believed that subsequent events evidence is not obtained circumstantially.

The auditors who think that subsequent events evidence is obtained when the audit procedures are carried out for that express purpose constituted $66.67 \%$ of the participants. Thus, it can be seen that the answers to the first two questions in this section support each other. The majority of the participants argued that the evidence will not be obtained circumstantially, but by carrying out audit procedures, especially regarding this issue.

In response as to whether subsequent events evidence is found with routine accounts, the results were as follows: $36 \%$ disagreed, $35.11 \%$ were undecided, $24.07 \%$ agreed, $2.78 \%$ strongly disagreed and $1.85 \%$ strongly agreed. It can be seen that the majority of the participants (mean $=2.8$ ) disagreed that subsequent events evidence generally emerges in routine accounts.

Auditors who responded to the survey are more likely to support the idea that evidence relating to subsequent events comes out in unusual accounts rather than routine accounts, as evidenced by the results being slightly above the average (mean=3.09).

Most of the independent auditors (mean=3.5) argued that the budgeted time can be exceeded during the search for subsequent events evidence, but also believed that obtaining subsequent events evidence reduces the restatement of financial statements and audit failures (mean=3.6).

Table 3. The Frequency of Obtaining Subsequent Events Evidence

\begin{tabular}{lllll}
\hline & & Number & Percentage & Mean \\
\hline The subsequent events evidence are & Strongly Agree & 3 & $2.78 \%$ & \\
obtained circumstantially. & Agree & 18 & $16.67 \%$ & \\
& Neutral & 17 & $15.74 \%$ & 2.4907 \\
& Disagree & 61 & $56.48 \%$ & \\
& Strongly Disagree & 9 & $8.33 \%$ & \\
\hline $\begin{array}{l}\text { The subsequent events evidence are } \\
\text { obtained when the audit procedures }\end{array}$ & Strongly Agree & 15 & $13.89 \%$ & \\
are carried regarding this issue. & Agree & 72 & $66.67 \%$ & \\
& Neutral & 12 & $11.11 \%$ & 3.8611 \\
& Disagree & 9 & $8.33 \%$ & \\
\hline $\begin{array}{l}\text { The subsequent events evidence } \\
\text { usually come out with routine } \\
\text { accounts. }\end{array}$ & Strongly Disagree & 0 & $0.00 \%$ & \\
& Strongly Agree & 2 & $1.85 \%$ & \\
& Agree & 26 & $24.07 \%$ & \\
& Neutral & 38 & $35.19 \%$ & 2.8611 \\
& Disagree & 39 & $36.11 \%$ & \\
\hline
\end{tabular}




\begin{tabular}{lllll}
\hline $\begin{array}{l}\text { The subsequent events evidence } \\
\text { usually come out with unusual }\end{array}$ Strongly Agree & 4 & $3.70 \%$ & \\
accounts. & Agree & 35 & $32.41 \%$ & \\
& Neutral & 36 & $33.33 \%$ & 3.0926 \\
& Disagree & 33 & $30.56 \%$ & \\
& Strongly Disagree & 0 & $0.00 \%$ & \\
\hline & Strongly Agree & 5 & $4.63 \%$ & \\
The budgeted time can be exceeded & Agree & 67 & $62.04 \%$ & 3.5185 \\
during searching subsequent events & Neutral & 16 & $14.81 \%$ & \\
evidence. & Disagree & 19 & $17.59 \%$ & \\
& Strongly Disagree & 1 & $0.93 \%$ & \\
\hline $\begin{array}{l}\text { Obtaining subsequent events } \\
\text { evidence reduces the restatement of } \\
\text { financial statements and audit } \\
\text { failures. }\end{array}$ & Strongly Agree & 7 & $6.48 \%$ & 3.6019 \\
& Neutral & 66 & $61.11 \%$ & $19.44 \%$ \\
& Disagree & 21 & $12.04 \%$ & \\
& Strongly Disagree & 1 & $0.93 \%$ & \\
\hline
\end{tabular}

\subsection{The Importance of Subsequent Events Disclosures}

The unlimited number of events that occurred after the reporting period are grouped under 19 titles based on listed real sector companies' subsequent events disclosures between the years 2009 and 2013 in Turkey. In order to determine the importance of the events that are described in the subsequent events disclosures, 19 disclosures are arranged and auditors that have responded to the survey are requested to evaluate them with the five-point Likert. Imputed importance and average degrees of the disclosures are given in Figure 1.

Disclosures on merge/division (mean $=4.48$ ); disclosures on subsidiaries, associates and other related parties (mean=4.35); disclosures on capital (mean=4.27); disclosures on securities (mean=4.18) and disclosures on indebtedness (mean=4.16) are the five disclosures that are considered to be the most important in the footnote disclosures about subsequent events. When this five-footnote information is analyzed, it is seen that the auditors who have responded to the survey rate the most common footnote disclosures important. Indeed, disclosures on subsidiaries, associates, and other related parties; disclosures on capital; and disclosures on securities are the most common of the top five disclosures.

According to Figure 1, the least common five disclosures are disclosures on natural disasters (mean=3.62), disclosures on changes in foreign exchange rates (mean=3.65), disclosures on legislation $($ mean $=3.65)$, disclosures on corporate governance $(m e a n=3.70)$ and disclosures on human resources (mean=3.75). When this five-footnote information is analyzed, it can be seen that the auditors responded that the least important disclosures are also the least encountered ones.

Although this five-footnote information is perceived to be the least important by the independent auditors, the average rating given this information varies between 3.62 and 3.76. Thus, it emerges that even this information is found important by the auditors. 


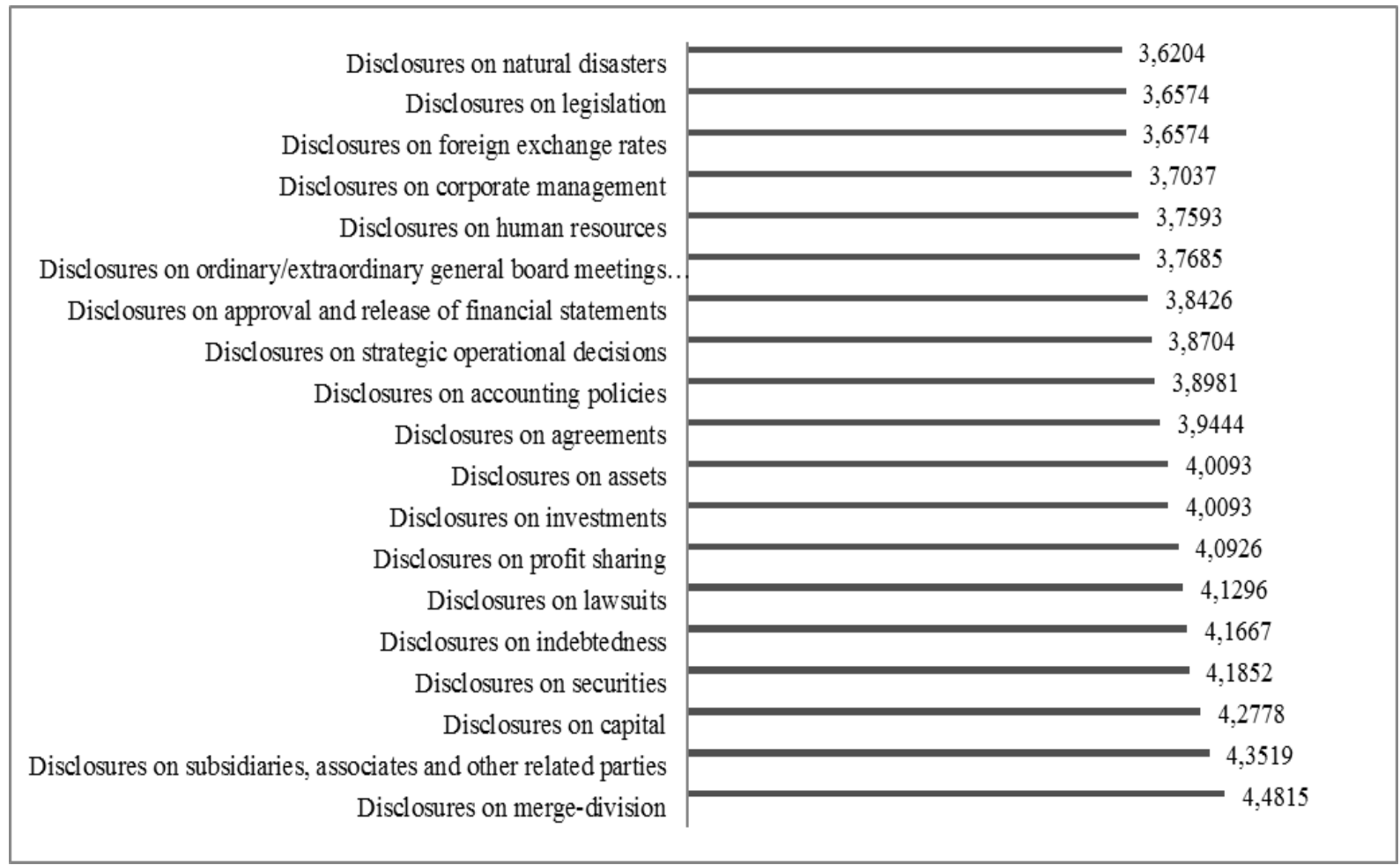

Figure 1. The Importance of Subsequent Events Disclosures

\subsection{Perceptions About the Importance of Subsequent Events}

In order to measure the perceptions of independent auditors about the subsequent events, statements are arranged by using the five-point Likert scale.

The majority of the participants (mean=3.98) stated that subsequent events are at a level that will affect investment decisions. The auditors who thought the events after the reporting period were at a level that will affect the independent audit opinion are the majority (mean=3.64). Considering that the events that will occur after the reporting period are in an unlimited framework, it can be stated that participants think that any of the footnote disclosures can affect the investors' and the auditors' decisions about the entity.

The participants' responses to the statement that the subsequent events are important enough to affect a single account are as follows: $5.56 \%$ strongly agree, $32.41 \%$ agree, $37.96 \%$ neutral, $22.22 \%$ disagree and $1.85 \%$ strongly disagree.

The participants' responses to the statement that the subsequent events are important enough to affect all of the financial statements are as follows: $11.11 \%$ strongly agree, $43.52 \%$ agree, $29.63 \%$ neutral, $13.89 \%$ disagree, $1,85 \%$ strongly disagree.

The majority of the participants (mean=3. 29) believe that obtaining evidence relating to subsequent events is more important than the timeliness of financial reporting. Considering that an event after any reporting period affects all the financial statements and independent audit opinion, it can be deduced that auditors may abandon the timeliness of financial reporting in order to obtain the evidence which is thought to be so important. 
Table 4. The Measurement of Perceptions About the Importance of Subsequent Events

\begin{tabular}{|c|c|c|c|c|}
\hline & & Number & Percentage & Mean \\
\hline \multirow{5}{*}{$\begin{array}{l}\text { The subsequent events are } \\
\text { important enough to affect the } \\
\text { investment decisions. }\end{array}$} & Strongly Agree & 26 & $24.07 \%$ & \multirow{5}{*}{3.9815} \\
\hline & Agree & 60 & $55.56 \%$ & \\
\hline & Neutral & 16 & $14.81 \%$ & \\
\hline & Disagree & 6 & $5.56 \%$ & \\
\hline & Strongly Disagree & 0 & $0.00 \%$ & \\
\hline \multirow{5}{*}{$\begin{array}{l}\text { The subsequent events are } \\
\text { important enough to affect the } \\
\text { independent audit opinion. }\end{array}$} & Strongly Agree & 16 & $14.81 \%$ & \multirow{5}{*}{3.6481} \\
\hline & Agree & 52 & $48.15 \%$ & \\
\hline & Neutral & 26 & $24.07 \%$ & \\
\hline & Disagree & 14 & $12.96 \%$ & \\
\hline & Strongly Disagree & 0 & $0.00 \%$ & \\
\hline \multirow{5}{*}{$\begin{array}{l}\text { The subsequent events are } \\
\text { important enough to affect a } \\
\text { single account. }\end{array}$} & Strongly Agree & 6 & $5.56 \%$ & \multirow{5}{*}{3.1759} \\
\hline & Agree & 35 & $32.41 \%$ & \\
\hline & Neutral & 41 & $37.96 \%$ & \\
\hline & Disagree & 24 & $22.22 \%$ & \\
\hline & Strongly Disagree & 2 & $1.85 \%$ & \\
\hline \multirow{5}{*}{$\begin{array}{l}\text { The subsequent events are } \\
\text { important enough to affect all the } \\
\text { financial statements. }\end{array}$} & Strongly Agree & 12 & $11.11 \%$ & \multirow{5}{*}{3.4815} \\
\hline & Agree & 47 & $43.52 \%$ & \\
\hline & Neutral & 32 & $29.63 \%$ & \\
\hline & Disagree & 15 & $13.89 \%$ & \\
\hline & Strongly Disagree & 2 & $1.85 \%$ & \\
\hline \multirow{5}{*}{$\begin{array}{l}\text { Obtaining evidence relating to } \\
\text { subsequent events is more } \\
\text { important than the timeliness of } \\
\text { financial reporting. }\end{array}$} & Strongly Agree & 8 & $7.41 \%$ & \multirow{5}{*}{3.2963} \\
\hline & Agree & 43 & $39.81 \%$ & \\
\hline & Neutral & 31 & $28.70 \%$ & \\
\hline & Disagree & 25 & $23.15 \%$ & \\
\hline & Strongly Disagree & 1 & $0.93 \%$ & \\
\hline
\end{tabular}

\subsection{Application Level of Turkish Auditing Standards in the Search of the Subsequent Events}

In this section statements aimed at determining the application level of audit procedures of Turkish Auditing Standards in the search of the subsequent events are discussed.

Although the investigation found that the average of the procedures ranges from 4.14 to 3.83 , it can be deduced that auditors often use all of the presented procedures. It is understood that the most-used presented procedures by auditors (mean $=4$. 14) are the ones querying legal advisors of the entity concerning opening or terminating cases and claims submitted to judicial authorities and expansion of the investigation if written or oral inquiry had been done about related issues in the past.

Questioning of management and/or senior management about whether a subsequent event that will affect financial statements has occurred is ranked second (mean= 4.08). Reading the minutes of the meeting held after the date of the financial statements and questioning the shareholders who attended the meeting, management and/or senior management about the issues in the report ranked third (mean=4).

The procedure of examining the latest interim financial reports after the reporting period of the entity in the current date takes fourth place (mean=3.95) in terms of frequency of occurrence of procedures.

The least used procedures are the reading of the last budget of the current period after the date of the financial statements, cash flow forecasts and other related management reports (mean=3.87) and the examination of procedures used by the management to determine the subsequent events (mean=3.83). 
However, as the average of the procedures used least ranges from 3.83 to 3.87, it reveals that the auditors' response about using a level of Turkish Auditing Standards in the search for subsequent events is high.

Table 5. Application Level of Turkish Auditing Standards in the Search of the Subsequent Events

\begin{tabular}{|c|c|c|c|c|}
\hline & & Number & Percentage & Mean \\
\hline \multirow{5}{*}{$\begin{array}{l}\text { Procedures used by the management to determine the } \\
\text { subsequent events are examined. }\end{array}$} & Always & 24 & $22.22 \%$ & \multirow{5}{*}{3.8333} \\
\hline & Often & 50 & $46.30 \%$ & \\
\hline & Sometimes & 27 & $25.00 \%$ & \\
\hline & Rarely & 6 & $5.56 \%$ & \\
\hline & Never & 1 & $0.93 \%$ & \\
\hline \multirow{6}{*}{$\begin{array}{l}\text { Management and/or senior management are questioned } \\
\text { about whether a subsequent event that will affect } \\
\text { financial statements have occurred or not. }\end{array}$} & Always & 39 & $36.11 \%$ & \multirow{5}{*}{4.0833} \\
\hline & Often & 44 & $40.74 \%$ & \\
\hline & Sometimes & 21 & $19.44 \%$ & \\
\hline & Rarely & 3 & $2.78 \%$ & \\
\hline & Never & 1 & $0.93 \%$ & \\
\hline & Always & 35 & $32.41 \%$ & \multirow{5}{*}{4.0093} \\
\hline \multirow{4}{*}{$\begin{array}{l}\text { The minutes of the meeting held after the date of the } \\
\text { financial statements are read and the shareholders who } \\
\text { attended the meeting, management and/or senior } \\
\text { management are questioned about the issues in the } \\
\text { report }\end{array}$} & Often & 47 & $43.52 \%$ & \\
\hline & Sometimes & 19 & $17.59 \%$ & \\
\hline & Rarely & 6 & $5.56 \%$ & \\
\hline & Never & 1 & $0.93 \%$ & \\
\hline \multirow{5}{*}{$\begin{array}{l}\text { The latest interim financial reports after the reporting } \\
\text { period of the entity are examined in the current date. }\end{array}$} & Always & 27 & $25.00 \%$ & \multirow{5}{*}{3.9537} \\
\hline & Often & 54 & $50.00 \%$ & \\
\hline & Sometimes & 23 & $21.30 \%$ & \\
\hline & Rarely & 3 & $2.78 \%$ & \\
\hline & Never & 1 & $0.93 \%$ & \\
\hline \multirow{5}{*}{$\begin{array}{l}\text { The last budget of the current period after the date of } \\
\text { the financial statements, cash flow forecasts and other } \\
\text { related management reports are read. }\end{array}$} & Always & 29 & $26.85 \%$ & \multirow{5}{*}{3.8796} \\
\hline & Often & 46 & $42.59 \%$ & \\
\hline & Sometimes & 25 & $23.15 \%$ & \\
\hline & Rarely & 7 & $6.48 \%$ & \\
\hline & Never & 1 & $0.93 \%$ & \\
\hline \multirow{5}{*}{$\begin{array}{l}\text { Legal advisors of the entity are questioned about } \\
\text { opening or terminating case and claims submitted to } \\
\text { judicial authorities. But if written or oral inquiry had } \\
\text { been done about related issues in the past, the } \\
\text { investigation is expanded. }\end{array}$} & Always & 43 & $39.81 \%$ & \multirow{5}{*}{4.1481} \\
\hline & Often & 44 & $40.74 \%$ & \\
\hline & Sometimes & 16 & $14.81 \%$ & \\
\hline & Rarely & 4 & $3.70 \%$ & \\
\hline & Never & 1 & $0.93 \%$ & \\
\hline
\end{tabular}

\section{Conclusion}

The survey carried out on the audit of subsequent events was applied to 108 independent auditors. Most of the auditors who have responded to the survey work in a medium- and large-scale international audit firms and audit non-listed companies. Most of the participating auditors have an undergraduate degree, are between 26-40 years of age and have the title "auditor." These auditors have stated that they possess good knowledge of IAS and ISA.

The statements of the auditors about performing most of the auditing work after the end of the period indicate strongly that the events after the reporting period are very important in nature, because the audit of the events that can occur after the reporting period is carried out in a subsequent process after the financial end of the period. Furthermore, percentage of auditors who have obtained event evidence after the reporting area more than two times 
during the past financial year is notable, and also that they have obtained this evidence by working less than 2 hours within a month after the end of the financial year. It was also found that the evidence obtained by the auditors is about event type that does not require much adjustment and they have obtained this evidence by using audit procedures regarding events after the reporting period. The assertion that subsequent events can be seen in unusual accounts rather than routine accounts is more dominant in the responses of participants. It can be seen that, according to the responses, audits can exceed the budgeted time during evidence search regarding events after the reporting period, because obtaining this evidence reduces the restatement of financial statements and audit failures.

In the survey all the disclosures about the events occurring after the reporting period have been considered as important by the participants. Disclosures on subsidiaries, associates, and other related parties; disclosures on capital and disclosures on securities are the footnote information were ranked by the participants as very important. Although still considered important, the footnote information the auditors considered the least significant were disclosures on corporate governance, disclosures on legislation and disclosures on decisions of the minutes of the meeting of the general assembly. Auditors stated that disclosures regarding subsequent events are important enough to affect the independent audit opinion and investment decisions. Furthermore, they consider them important enough to affect all the financial statements. Auditors use the audit procedures of Turkish Independent Audit Standards in the searching process of the subsequent events.

This study has a limitation. This research was carried out only in Istanbul/Turkey. Further research could extend to other cities in Turkey or to emerging countries so that their subsequent events disclosures and audit approaches could be compared.

\section{References}

Bozkurt, N. (2011). Muhasebe denetimi. İstanbul: Beta Yayınları.

Capital Market Boards of Turkey. (2013). Borsada işlem gören şirketlerin yükümlülükleri, Retrieved June 30, 2014, from http://www.spk.gov.tr/indexcont.aspx?action=showpage\&menuid=12\&pid=0\&subid=5.

Chung, J.O.Y, Cullinan C.P, Frank M, Long J.H, Phillips J.M \& O'Reilly D.M. (2013). The auditor's approach to subsequent events: Insights from the academic literature. Auditing: A Journal of Practice \&Theory, 32(1), 167-207. http://dx.doi.org/10.2308/ajpt-50328

Fitzsimons, A., Pappas, A. \& Ramanujam, S. (2009). FASB Proposes Statements to Address Subsequent Events and Going Concern. Commercial Lending Review, Mar-Apr, 34-38.

Giacosa, E. (2012). Disclosures in events after the balance sheet date: A study of selected Italian companies. World Journal of Social Sciences, 2(5), 262-285.

Gönen, S. \& Kutay N. (2013). Finansal tablo kullanıcılarının karar almalarında TMS 10 raporlama döneminden (Bilanço tarihinden) sonraki olayların önemi, Uluslararası Alanya Işsletme Fakültesi Dergisi, 3(5), 39-46.

Gücenme U, Arsoy A.P, Ertan Y. \& Bora T. (2014). TMS/TFRS'ye dönüştürülen finansal tabloların denetim modelinin özellikleri, Journal of Accounting and Finance, 16(64), 1-26.

Gramling, Audrey A., K. M. Johnstone \& L. E. Littenberg. (2012) Auditing, (8th. ed.), USA: South Western Cengage Learning.

Herda, D.N, \& Lavelle J.J. (2014). Auditing subsequent events, Current Issues in Auditing, 8(2), 10-24. http://dx.doi.org/10.2308/ciia-50886

Janvrin, D.J. \& Jeffrey C. (2007). An investigation of auditor perceptions about subsequent events and factors that influence this audit task. Accounting Horizons, 21(3), 295-312. http://dx.doi.org/10.2308/acch.2007.21.3.295

Kılıç, M., Uyar A. \& Ataman, B. (2014). Preparedness for and perception of IFRS for SMEs: evidence from Turkey, Accounting and Management Information Systems, 13(3), 492-519.

Mirza, A.A., Magnus O. \& Graham J.H. (2011). IFRS practical implementation guide and workbook, Third Edition, USA: John Wiley Sons Inc.

Muthupandian, K.S. (2008). IAS 10: Events after reporting period-a closer look, The Management Accountant MPRA Paper Series, 11(43).

Nawaiseh M.A.L. \& Jaber J. (2015). Auditing subsequent events from the perspective of auditors: study from Jordan, International Journal of Financial Research, 6(3), 78-85. http://dx.doi.org/10.5430/ijfr.v6n3p78

Ozdemir, Z. \& Ataman Gokcen, B. (2015). Raporlama döneminden sonraki olayların incelenmesi: payları borsada 
islem goren sirketler uzerine bir arastırma, World of Accounting Science, 17(3), 437-466.

Pamukçu, F. \& Pamukcu P. (2009). Bilanço tarihinden sonraki olaylar (TMS-10) ve finansal tablolara etkiler. Mali Çözüm Dergisi, 91(1), 67-80.

Puttick, G. \& Esch S. (2007). The principles and practice of auditing, (9th ed.), South Africa: Juta.

Rossi III, John D. (2011). A look at subsequent events, Pennsylvania CPA Journal. 81(4), 1-2.

Şen, İ.K. (2015). Uluslararası finansal raporlama ve uluslararası denetim standartlarında raporlama döneminden sonraki olaylar, Muhasebe ve Denetime Bakıs, 15(45), 131-147.

Turel, A. (2012). Bilanço tarihinden sonra ortaya çıkan satış iadeleri ile ilgili finansal raporlama yaklaşımları, Mali Çözüm, Sep-Dec, 109-122.

Uyar, A. \& Güngörmüs, A.H. (2013). Perceptions and knowledge of accounting professionals on IFRS for SMEs: evidence from Turkey, Research in Accounting Regulation, 25, 77-87. http://dx.doi.org/10.1016/j.racreg.2012.11.001

Uyar, S. (2014). Bilanço tarihinden sonraki olaylar, Retrieved July 30, 2014, from http://www.kgk.sakarya.edu.tr/r.pdf

Yılmaz, F. \& Sarı E. (2013). Raporlama döneminden (Bilanço tarihinden) sonraki olayların Tms açısından değerlendirilmesi ve İmkb-100 endeksindeki şirketler üzerinde bir araştırma. Turkey, June 19-22 2013. III.International Conference on Luca Pacioli in Accounting History and III. Balkans and Middle East Countries Conference on Accounting and Accounting History.

Yükçü, S. \& Yasar, S. (2013). TMS 10 raporlama tarihinden (Bilanço tarihinden) sonraki olaylar standardına ilişkin uygulamalar. Mali Çözüm Dergisi, Ocak - Şubat, 15-30. 